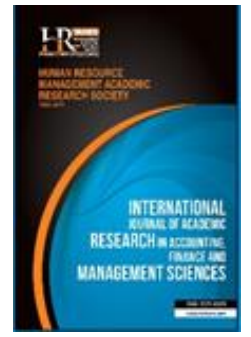

International Journal of Academic Research in Accounting, Finance and Management Sciences

Vol. 8, No.2, April 2018, pp. 132-142

E-ISSN: 2225-8329, P-ISSN: 2308-0337

(C) 2018 HRMARS

www.hrmars.com

To cite this article: Anghelache, C., Barbu, C.-M., Anghel, M.-G., Marinescu, A.-I. (2018). Statistical Analysis of the Evolution of Humanity by Population and Resources, International Journal of Academic Research in Accounting, Finance and Management Sciences 8 (2): 132-142.

\title{
Statistical Analysis of the Evolution of Humanity by Population and Resources
}

\section{Constantin ANGHELACHE ${ }^{1}$, Cristian-Marian BARBU ${ }^{2}$, Mădălina-Gabriela ANGHEL ${ }^{3}$, Andreea-loana MARINESCU ${ }^{4}$}

1Bucharest University of Economic Studies/„Artifex” University of Bucharest, Romania, ${ }^{1}$ E-mail: actincon@yahoo.com

2,3 "Artifex" University of Bucharest, Romania,

${ }^{2}$ E-mail: barbu cristianmarian@yahoo.com, ${ }^{3} E$-mail: madalinagabriela anghel@yahoo.com, ${ }^{4}$ Bucharest University of Economic Studies, Romania, ${ }^{4}$ E-mail: marinescu.andreea.ioana@gmail.com

\begin{abstract}
At present, the term globalization is an all-embracing one, which, starting from certain economic and social developments, from exploited, exploitable or prospective natural resources, all researchers agree that a globalization process is required in the future. Globalization is a global perspective, taking into account the proximity, sometimes the merging of interests and the perspective of the evolution of countries around the world. There are plenty of researchers who have been exploring the evolution on Terra and, on the basis of the data they have given, have come to conclusions that are not positive, hope-giving. In the meantime, to say, synthetically, the world's population has reached 7.2 billion inhabitants in 2017, and forecasting predicts that in 2050 this world population will reach about 10 billion people. A structural analysis across continents and countries leads to the conclusion that the demographic explosion has passed from the Asian continent specific decades ago in the African continent. All African countries, of course, in different percentages, have a very special female fertility which leads to high birth rates. On the other hand, Europe, the most technologically advanced, industrial, and research-intensive continent in all areas, has a fairly low birth rate of 1.48 on average. Asia has a fertility of 2.2 children born to a woman, and in the North American continent and South America, fertility is at a somewhat controllable level, not to say otherwise. Analyzing natural resources, at the same time as the level of technological and scientific-scientific development, we come to the conclusion that resources are consumable and that substitutes or the development of the same resources are a slightly more delicate problem. There is much talk about substitutes, but it does not replace the natural resources that all humanity needs. We are talking about chewing food resources or replacing traditional resources with others undergoing industrial processes. In antithesis, the evolution of the population with the resources on the globe, we come to the conclusion of a shortage of resources on the background of a rise in birth rates, a context in which the level of living is raised, as long as in Africa 63\% of the population has a subsistence level under $\$ 1 /$ day, and $90 \%$ of the African population under \$2. They are thoughtful elements to prefigure the perspective of human evolution. Also, in order to reveal the discrepancy that exists between the states of the world in terms of the current level of development (to highlight the updated evolutionary trend, we used statistical series on time intervals, according to available data, 2012, 1961-2012, 1980-2012 or 1991-2012), we used a socio-economic analysis, taking into account the most representative indicators, such as: Gross Domestic Product per capita; Gross domestic product per employee (productivity of national labor); occupancy rate and unemployment rate.
\end{abstract}

Key words

Population, resources, unemployment, Gross Domestic Product, Population Employment Rate

Received: 12 May 2018 (c) The Authors 2018

Revised: 02 Jun 2018 Published by Human Resource Management Academic Research Society (www.hrmars.com)

Accepted: 10 Jun 2018 This article is published under the Creative Commons Attribution (CC BY 4.0) license. Anyone may reproduce, distribute, translate and create derivative works of this article (for both commercial and noncommercial purposes), subject to full attribution to the original publication and authors. The full terms of this license may be seen at: http://creativecommons.org/licences/by/4.0/legalcode 


\section{Introduction}

In this article, the authors relied on a broad study on the perspective of human evolution in terms of living standards, ensuring living conditions and, last but not least, avoiding crises that occur in the field of resources, how such as water, agriculture, wooded areas, mineral resources of all kinds and many others that can generate elements of instability and concern for the future of mankind.

The evolution of the world population, continents and countries is being analyzed, one by one, highlighting and presenting charts that reveal the current situation on the continent, and from the forecasting study carried out until 2050 it is concluded that the state of things are not attenuated but, on the contrary, complicated by the appearance of serious problems related to the living conditions of the population.

The authors come to some conclusions, which they exemplify with concrete cases related to the explosive growth of the population in parallel with the diminishing of resources and the occurrence of substitutes and substitutes, a situation that is not auspicious. In the study, convincing figures are presented in connection with the intensification of the immigration process from Africa to Europe and somewhat to North America or Latin America. This is due to an explosive birth rate in the African countries, as compared with the year-on-year decrease in the population of all European countries.

The study extends to the evolution of indicators from countries of the world, from all continents, over a period of time. These elements of the study express the current level of development of the countries considered and the perspective of their evolution.

The authors refer to the role of the European Union in ensuring protection and trying to find solutions other than immigration, in order to be able to master and create more reasonable conditions for the population of African continent countries.

From the study, the authors do not draw pessimistic conclusions but alarm signals about the need for developed euro area countries, former empire countries, and even other countries with a higher level of development to descend to the level of understanding and try to find of global solutions to ensure the improvement of the living conditions perspective across the globe.

\section{Literature review}

Anghelache et al. (2018) conducted a study on the evolution of the population in the context of global resources as well as the prospects for global economic and financial evolution. Anghelache (2017) analyzed and interpreted Romania's socio-economic evolution. Anghelache and Anghel (2017) carried out a complex analysis of the results recorded by Romania in the ten years since it was a member of the European Union, compared to the other states in the Union. Anghelache and Anghel (2017) analyzed the European Union's Strategy for Improving Living Conditions on Total, as well as in each Member State of the Community, which aims to alleviate and even eliminate the various situations affecting the population of some countries. Anghelache and Anghel (2016) presented the statistical indicators used in economic analyzes. Anghelache (2008) is a reference work in the field of economic and theoretical statistics. Benjaminsen, Holden, Lund and Sjaastad (2009) conducted a study on land rights in Africa. Canadell and Raupach (2008) presented issues related to forest management to mitigate climate change. DeFries et al. (2010) analyzed the correlation between urban population growth and deforestation. Das and Mohanty (2012) studied the "fertility" indicator in India. Dudgeon, Arthington, Gessner, et al. (2006) explored the peculiarities of freshwater habitats and the biodiversity they support, making them particularly vulnerable to human activities. Fargione et al. (2008) analyzed the effects of biofuels on the environment. Headey and Hodge (2009) studied the effect of population growth on economic growth. Holden and Otsuka (2014) investigated the importance of land ownership reforms in terms of population growth and increased land use in Africa. Jorgenson and Burns (2007) investigated the effects of population dynamics and national development on deforestation in less developed countries. Mendez and Popkin (2004) studied aspects of urbanization and globalization. Mishra (2008) conducted an analysis of the correlation between demographic change and global economic growth. Montgomery presented (2008) aspects of urban demographic transformation, with an emphasis on estimates and forecasts of urban population aggregates. Olson, D. et al. (2001) presented a new life map on Earth that offers features that enhance utility for global 
and regional conservation planning. Wittemyer, Elsen, Bean, Burton and Brashares (2008) analyzed the effects of accelerating the growth of the human population.

\section{Research methodology and data. Results and discussions}

\section{- Comparative analysis of the state of the world states in 2017 and the forecast}

The evolution of humankind can be approached under the most diverse aspects. There are macroeconomic indicators (population, occupied population, Gross Domestic Product, Gross Domestic Product per employee or per capita, purchasing power parity, unemployment, etc.) that can form the basis of a global analysis in order to identify and forecast the future humankind.

Based on the data in table 1, Gross Domestic Product per capita in some countries, we have presented this indicator in absolute figures over the years that we considered significant from 1961 to 2012.

Table 1. Gross Domestic Product per capita in some states during 1961-2012

\begin{tabular}{|l|r|r|r|r|r|r|r|}
\hline Country Name & \multicolumn{1}{|c|}{$\mathbf{1 9 6 1}$} & \multicolumn{1}{|c|}{$\mathbf{1 9 7 0}$} & \multicolumn{1}{|c|}{$\mathbf{1 9 8 0}$} & \multicolumn{1}{c|}{$\mathbf{1 9 9 0}$} & \multicolumn{1}{c|}{$\mathbf{2 0 0 0}$} & \multicolumn{1}{c|}{$\mathbf{2 0 1 0}$} & \multicolumn{1}{|c|}{$\mathbf{2 0 1 2}$} \\
\hline Australia & 1878.3 & \multicolumn{1}{|c|}{3304.6} & 10207 & 18247 & 21678 & 51746 & 67556 \\
\hline Belgium & 1350.2 & 2732.2 & 12707 & 20350 & 22697 & 42960 & 43372 \\
\hline Brazil & 203.19 & 440.64 & 1930.5 & 3086.9 & 3694.5 & 10978 & 11340 \\
\hline China & 75.873 & 111.82 & 193.02 & 314.43 & 949.18 & 4433.4 & 6091 \\
\hline Cameroon & 120.12 & 171.32 & 754.66 & 923.88 & 583.09 & 1090.6 & 1166.9 \\
\hline Colombia & 276.12 & 337.24 & 1240.1 & 1209.2 & 2503.5 & 6179.4 & 7747.8 \\
\hline Czech Republic & - & - & - & 3786.9 & 5724.8 & 18867 & 18683 \\
\hline Germany & - & 2672 & 11746 & 21584 & 22946 & 40145 & 41863 \\
\hline Algeria & 210.61 & 331.06 & 2174.3 & 2364.5 & 1727.3 & 4349.6 & 5347.7 \\
\hline Egypt & 150.56 & 211.39 & 509.94 & 765.58 & 1509.6 & 2803.5 & 3256 \\
\hline Spain & 450.05 & 1177.1 & 6036.6 & 13410 & 14414 & 29863 & 28624 \\
\hline France & 1445.2 & 2821.8 & 12500 & 21301 & 21775 & 39186 & 39772 \\
\hline Hungary & - & 536.13 & 2069.2 & 3186.4 & 4542.7 & 12750 & 12531 \\
\hline India & 87.043 & 114.4 & 271.25 & 375.89 & 457.28 & 1419.1 & 1489.2 \\
\hline Iran & & 370.13 & 2315.3 & 2058.8 & 1536.7 & 5674.9 & \\
\hline Italy & 887.34 & 2029.9 & 8148.1 & 20065 & 19388 & 33761 & 33072 \\
\hline Morocco & 159.21 & 247.37 & 943.42 & 1037.3 & 1275.9 & 2822.7 & 2902.3 \\
\hline Moldova & - & - & - & 972.09 & 354 & 1631.5 & 2037.6 \\
\hline Mali & - & 62.938 & 265.37 & 304.01 & 236.1 & 673.69 & 693.98 \\
\hline Mauritania & 121.95 & 182.21 & 462.17 & 503.71 & 477.7 & 1017.2 & 1106.1 \\
\hline Niger & 141.66 & 147.29 & 429.97 & 319.93 & 163.64 & 359.8 & 394.78 \\
\hline Nigeria & 96.812 & 223.51 & 871.15 & 321.67 & 377.5 & 1437 & 1555.4 \\
\hline Romania & - & - & - & 1650.7 & 1651 & 7670.3 & 9036 \\
\hline Senegal & 256.14 & 242.96 & 629.08 & 760.79 & 474.52 & 998.6 & 1023.3 \\
\hline Slovak Republic & - & - & - & 2211 & 5330.4 & 16036 & 16847 \\
\hline Slovenia & - & - & - & 8698.9 & 10045 & 22898 & 22000 \\
\hline Sweden & 2147.2 & 4493.4 & 16221 & 29026 & 27869 & 49360 & 55041 \\
\hline Swaziland & 120.34 & 251.52 & 898.3 & 1292.1 & 1433.2 & 3093.5 & 3041.9 \\
\hline Tunisia & 202.5 & 280.72 & 1369.5 & 1507.2 & 2245.3 & 4206.8 & 4236.8 \\
\hline Turkey & 284.01 & 491.4 & 1566.7 & 2790.6 & 4219.5 & 10135 & 10666 \\
\hline United States & 2934.6 & 5247 & 12598 & 23955 & 36467 & 48358 & 51749 \\
\hline
\end{tabular}

Note: GDP per capita is the gross domestic product divided by the mid-year population. GDP is the sum of the gross value added of all resident producers in the economy plus any taxes on product and minus subsidies not included in the value of the products. It is calculated without deducting the depreciation of the manufactured goods or the depletion and degradation of natural resources. Data is in current US dollars.

Source: World Development Indicators, data processed by the authors. 
The data are expressed in US dollars and they reveal different evolutions of some countries from time to time. We have included states from all continents to make this interpretation pertinent in terms of the evolution of this indicator that best regulates the appreciation of the evolution of some states. If some countries, such as the Czech Republic, Germany, Hungary, Moldova, the Slovak Republic, Slovenia or Romania, did not report data for the years 1961-1970, of course we put down dashes, but later on, 1990 to 2012 are significant. There is no centrally-based data on post-2013 developments, but trends that have taken place until 2012 are somewhat the same for the next period.

We find that in Europe, countries such as Belgium, Germany, France, Spain, Sweden have achieved good results, increasing this indicator, for example in the case of Germany, from \$2,772 in 1970 to $\$ 4863$ in 2012. France from 1445, $\$ 2$ in 1961 reaches $\$ 39,722$ per capita in 2012. We can also remember Switzerland, which in 1961 had a gross domestic product per capita of $\$ 2146.2$ and reached 2012 at \$ 55041 per capita. I have included in this presentation also some states in Europe, such as the Czech Republic; Hungary, Romania, Slovak Rep., Slovenia, countries that have entered the European Union in the latest wave, and of course gross domestic product has increased in an accelerated or not, because we can not make such a big comparison because we do not have data for this. However, we have focused on comparing the data from 1990 to 2012. For example, in the Czech Republic, from $€ 3786.9$ per capita in 1990 to 18683 euro per inhabitant in 2012. Hungary had 536.13 in 1990 dollars per capita, and reached 12531 in 2012. Romania recorded \$1,650 per capita in 1990 and reached 9036 dollars per inhabitant in 2012 , thus revealing a remarkable growth. As for the situation in the Slovak Republic increased from \$ 2219 per capita in 1990 to $\$ 16846$ per capita in 2012, and Slovenia a country deserted from the former Yugoslavia increased from $\$ 8698$ per capita to $\$ 22,000$ per capita in 2012. China is making good progress from $\$ 75.8$ per capita in 1961 to $\$ 6091$ in 2012. China's economy's tremendous evolution can be seen. In the Asian continent, we also talked about Iran and India, starting in 1961 from $\$ 86.43$ per capita to $\$ 14122$ in 2012. As far as the United States is concerned, we find that in 1961 there was a product per capita gross domestic product in 1961 of $\$ 2964.6$ and reached $\$ 51649$ per capita in 2012. Australia as a separate continental country recorded $\$ 1878.3$ per capita in 1961 and reached $\$ 67556$ per capita in 2012, basically being the highest level recorded by any country. In Latin America, we find that Brazil had a gross domestic product of $\$ 203.19$ per capita in 1961 and reached $\$ 11340$ per capita in 2012, and Colombia ranged from $\$ 276.12$ per capita reaching in 2012 to $\$ 11,669.8$ per capita. The situation in the countries of Africa is the most disastrous. For example, Algeria had \$210.61 per inhabitant, Egypt \$150.56 per capita, Cameroon \$ 120.12 per capita, Morocco 159.21, Mauritania \$129.25 per capita, Niger 141, \$ 66 per capita, Nigeria \$ 96.8 per capita, and Swaziland $\$ 120.34$ per capita. These countries reach quite high levels in 2012 . By way of example, we show that Algeria reaches \$ 5546.7 per inhabitant, Egypt \$ 3256 per inhabitant, Morocco \$ 2900.3 per capita, Mauritania $\$ 1906.1$ per capita, Niger $\$ 394.7$ per capita, and Tunisia $\$ 4236.8$ per capita. So, from the point of view of the results, taking into account the resources, taking into account the capacity utilization of the factors of production, the countries in the world are in a great discrepancy.

Based on the data in table 2, we then calculated gross domestic product per employee, ie labor productivity. We find that the order is roughly the same. Australia, Belgium, France, Sweden, Italy, had a very high gross domestic product per capita in 1980, which increased year on year and multiplied to very high figures.

Table 2. Gross domestic product per employee (labor productivity) in some countries during 1980-2012

\begin{tabular}{|l|c|c|c|c|c|c|}
\hline Country Name & $\mathbf{1 9 8 0}$ & $\mathbf{1 9 9 0}$ & $\mathbf{2 0 0 0}$ & $\mathbf{2 0 1 0}$ & $\mathbf{2 0 1 1}$ & $\mathbf{2 0 1 2}$ \\
\hline Australia & 33507 & 37050 & 45307 & 49196 & 49366 & 50652 \\
\hline Belgium & 37742 & 44588 & 51915 & 54772 & 54989 & 54858 \\
\hline Brazil & 12500 & 10474 & 12100 & 13495 & 13592 & 13557 \\
\hline China & 1655 & 2562 & 4660 & 13056 & 14203 & 15250 \\
\hline Cameroon & 3035 & 3203 & 2665 & 2772 & 2820 & 2882 \\
\hline Colombia & 12446 & 14356 & 14781 & 16840 & 17536 & 17990 \\
\hline Czech Republic & - & 17859 & 19909 & 26648 & 27081 & 26781 \\
\hline Germany & - & - & 39949 & 42699 & 43393 & 43243 \\
\hline Algeria & 15158 & 12262 & 9883 & 11225 & 11285 & 11394 \\
\hline Egypt & 6662 & 8493 & 10915 & 13079 & 13057 & 13051 \\
\hline
\end{tabular}




\begin{tabular}{|l|c|c|c|c|c|c|}
\hline Country Name & $\mathbf{1 9 8 0}$ & $\mathbf{1 9 9 0}$ & $\mathbf{2 0 0 0}$ & $\mathbf{2 0 1 0}$ & $\mathbf{2 0 1 1}$ & $\mathbf{2 0 1 2}$ \\
\hline Spain & $\mathbf{2 7 8 4 2}$ & 34373 & 38938 & 41483 & 42312 & 43297 \\
\hline France & 35621 & 43192 & 48744 & 52031 & 52668 & 52535 \\
\hline Hungary & 11989 & 12626 & 16218 & 20520 & 20772 & 20328 \\
\hline India & 2638 & 3531 & 5063 & 8515 & 8875 & 9200 \\
\hline Iran & 16490 & 15003 & 15581 & 19182 & 19256 & 18802 \\
\hline Italy & 34731 & 40941 & 47335 & 45680 & 45727 & 45053 \\
\hline Morocco & 7551 & 8140 & 7939 & 11528 & 11896 & 12051 \\
\hline Moldova & - & 16884 & 6227 & 13615 & 14600 & 15190 \\
\hline Mali & 2375 & 2596 & 2772 & 3422 & 3415 & 3165 \\
\hline Niger & 2860 & 1876 & 1344 & 1554 & 1532 & 1689 \\
\hline Nigeria & 3996 & 3514 & 3293 & 6025 & 6299 & 6567 \\
\hline Romania & 6933 & 5744 & 6350 & 11348 & 11544 & 11584 \\
\hline Senegal & 3367 & 3465 & 3441 & 3755 & 3738 & 3761 \\
\hline Slovak Republic & - & 15498 & 21837 & 32526 & 32990 & 33513 \\
\hline Slovenia & - & 22365 & 29296 & 36312 & 37127 & 36908 \\
\hline Sweden & 29178 & 33129 & 43307 & 51120 & 51857 & 52380 \\
\hline Tunisia & 10283 & 11279 & 13624 & 17538 & 17033 & 17320 \\
\hline Turkey & 11128 & 16041 & 19826 & 27710 & 28214 & 28490 \\
\hline United States & 41649 & 47907 & 58601 & 67190 & 68039 & 68374 \\
\hline
\end{tabular}

Note: GDP per person employed (constant 1990 PPP \$)

Source: World Development Indicators, data processed by the authors.

Belgium registered in $2012 \$ 34858$ per capita or labor productivity per employee, Germany reached $\$ 43,243$ per employee, Spain to $\$ 43,297$ per employee, Italy $\$ 45053$ per employee, Sweden $\$ 52,380$ per employee, The United States had a remarkable level in 1980, or $\$ 41,649$ per employee, reaching $\$ 68,374$ per employee in 2012. Asian countries can be mentioned in terms of China, which has grown from a labor productivity of 1,600 gross domestic product per employee in 1980 to $\$ 1,550$ per employee in 2012 , an increase of nearly ten times. African countries still maintain very low levels, for example Senegal \$3661 per employee, Cameroon \$ 2882 per employee in 2012, Mali \$ 3165 per employee, Niger \$ 1689 per employee. So, there are very low productivity, which also reveals the fact that in these countries in Africa the degree of capitalization of the resources that yield the results and then the degree of poverty that is getting higher.

To illustrate the global disparities between alarming population growth and the use of resources through the use of human potential, we presented in table 3, population employment data in some states, thereby understanding the ratio between people working and the total population able to work. In this table, the data is expressed as a percentage.

Table 3. Occupancy rate in some states in 1991-2012

\begin{tabular}{|l|r|r|r|r|r|r|r|}
\hline Country Name & $\mathbf{1 9 9 1}$ & $\mathbf{1 9 9 5}$ & $\mathbf{2 0 0 0}$ & $\mathbf{2 0 0 5}$ & $\mathbf{2 0 1 0}$ & $\mathbf{2 0 1 1}$ & $\mathbf{2 0 1 2}$ \\
\hline Australia & 57.2 & 58.4 & 59.4 & 61.2 & 62.1 & 62.3 & 61.9 \\
\hline Belgium & 45.8 & 45.7 & 48.8 & 48.7 & 49.4 & 49.2 & 49 \\
\hline Brazil & 60.2 & 65 & 61.7 & 63.7 & 64.5 & 65.3 & 65 \\
\hline China & 75 & 75 & 73.6 & 70.2 & 67.8 & 67.9 & 68 \\
\hline Cameroon & 63.9 & 66.3 & 64.7 & 66.1 & 67.2 & 67.3 & 67.5 \\
\hline Colombia & 46.6 & 50.4 & 54.2 & 59 & 59.3 & 59.9 & 60.3 \\
\hline Czech Republic & 59.9 & 58.9 & 55.2 & 54.6 & 54.1 & 54.3 & 54.7 \\
\hline Germany & 56.2 & 53.4 & 53.6 & 51.9 & 55.1 & 56.3 & 56.5 \\
\hline Algeria & 34 & 32.1 & 30.7 & 36.3 & 38.8 & 39.1 & 39.4 \\
\hline Egypt & 43 & 41.3 & 42 & 42.4 & 44.2 & 42.9 & 43.2 \\
\hline Spain & 42.4 & 38.9 & 45.5 & 51.4 & 47.2 & 46.4 & 44.4 \\
\hline France & 49.8 & 48.6 & 49.7 & 50.9 & 50.9 & 50.8 & 50.6 \\
\hline Hungary & 48.5 & 44.3 & 46 & 46.5 & 44.9 & 45.3 & 46.2 \\
\hline India & 58.4 & 58.1 & 56.6 & 58.1 & 53.5 & 53.6 & 53.7 \\
\hline
\end{tabular}




\begin{tabular}{|l|r|r|r|r|r|r|r|}
\hline Country Name & $\mathbf{1 9 9 1}$ & $\mathbf{1 9 9 5}$ & $\mathbf{2 0 0 0}$ & $\mathbf{2 0 0 5}$ & $\mathbf{2 0 1 0}$ & $\mathbf{2 0 1 1}$ & $\mathbf{2 0 1 2}$ \\
\hline Iran & 40.6 & 38.9 & 38.5 & 41.8 & 38.2 & 38.6 & 38.9 \\
\hline Italy & 45.2 & 41.6 & 42.6 & 45.2 & 44.2 & 44.1 & 43.8 \\
\hline Morocco & 46.2 & 47.6 & 46.3 & 46.5 & 45.5 & 45.7 & 45.8 \\
\hline Moldova & 61.7 & 60 & 54.8 & 45.1 & 38 & 38.8 & 37.7 \\
\hline Mali & 46.3 & 46.1 & 46.7 & 49.3 & 60.4 & 60.5 & 60.6 \\
\hline Mauritania & 32.1 & 32.7 & 34.1 & 35.4 & 36.9 & 37 & 37.1 \\
\hline Niger & 54.2 & 56.3 & 59.5 & 61.3 & 61.4 & 61.4 & 61.4 \\
\hline Nigeria & 52.8 & 52.5 & 51.7 & 50.7 & 51.4 & 51.6 & 51.7 \\
\hline Romania & 55 & 57.8 & 60.4 & 51.1 & 52 & 51.6 & 52.3 \\
\hline Senegal & 68 & 68.2 & 68 & 68.3 & 68.7 & 68.8 & 68.9 \\
\hline Slovak Republic & 58.7 & 52 & 48.8 & 49.9 & 50.5 & 51 & 51.2 \\
\hline Slovenia & 50.7 & 54.8 & 53.4 & 55.3 & 55 & 53.4 & 52.7 \\
\hline Sweden & 64.1 & 57.2 & 59.2 & 58.7 & 58 & 58.9 & 59 \\
\hline Tunisia & 41.2 & 41 & 40.2 & 40.2 & 41 & 41.2 & 41.4 \\
\hline Turkey & 51.8 & 49.4 & 45.6 & 41.2 & 42.7 & 44.6 & 44.9 \\
\hline United States & 60.5 & 62 & 63.6 & 61.6 & 57.4 & 57.3 & 57.8 \\
\hline Uzbekistan & 52.8 & 52.3 & 52.8 & 53 & 53.9 & 54.1 & 54.4 \\
\hline
\end{tabular}

Note: The population occupancy rate is calculated as the ratio of the population performing an activity according to the statistical methodology to the total population at the working age. Expressed as a percentage.

Source: World Development Indicators, data processed by the authors.

We find that the poorest countries, namely Algeria, Egypt, have the lowest weights respectively $34.43 \%$. The situation in Mauritania is particularly marked, with only $33.9 \%$ of the working population working. Of course, countries with outstanding results also have high employment. For example, Sweden has $64.1 \%$ of the employed population, the United States $60.5 \%$, Belgium $60.2 \%$. Asian and Australian countries have a lower share than European countries and North American countries, but far beyond African continent countries. Therefore, the list of the use of labor resources is determined by the level of economic development of the country. In order to make a structural analysis by field of activity, we will see that in Africa they are at a low level of technicalness and complexity of the economy. In 2012, we encounter approximately the same weights with small changes that are between the same margins, which means that during this 22-year period the mutations were somewhat reduced compared to a possible comparison of the population in each of the analyzed countries during that period.

Another indicator that gives the essence and meaning of our analysis is the unemployment rate calculated as a percentage of the total labor force in some countries in the period from 1990 to 2012, as shown in table 4.

Table 4. Unemployment rate in some countries during 1980-2012

\begin{tabular}{|l|r|r|r|r|r|r|r|}
\hline \multicolumn{1}{|c|}{ Country Name } & \multicolumn{1}{c|}{$\mathbf{1 9 9 0}$} & \multicolumn{1}{|c|}{$\mathbf{1 9 9 5}$} & \multicolumn{1}{c|}{$\mathbf{2 0 0 0}$} & \multicolumn{1}{c|}{$\mathbf{2 0 0 5}$} & $\mathbf{2 0 1 0}$ & $\mathbf{2 0 1 1}$ & $\mathbf{2 0 1 2}$ \\
\hline Australia & 6.9 & 8.5 & 6.3 & 5 & 5.2 & 5.1 & 5.2 \\
\hline Belgium & 7.2 & 9.3 & 6.6 & 8.4 & 8.3 & 7.1 & 7.5 \\
\hline Brazil & 3.7 & 6 & - & 9.3 & - & 6.7 & - \\
\hline China & 2.5 & 2.9 & 3.1 & 4.2 & - & - & - \\
\hline Colombia & 10.2 & 8.7 & 16.6 & 12 & 12 & 11.1 & 10.6 \\
\hline Czech Republic & - & 4 & 8.8 & 7.9 & 7.3 & 6.7 & 7 \\
\hline Germany & - & 8.1 & 7.7 & 11.1 & 7.1 & 5.9 & 5.4 \\
\hline Algeria & 19.8 & 27.9 & 29.8 & 15.3 & 10 & 10 & \\
\hline Egypt & 8.6 & 11.3 & 9 & 11.2 & 9 & 12 & 12.7 \\
\hline Spain & 16 & 22.7 & 13.9 & 9.2 & 20.1 & 21.6 & 25 \\
\hline France & 9.4 & 11.8 & 10.2 & 8.9 & 9.3 & 9.2 & 9.9 \\
\hline Hungary & - & 10.2 & 6.4 & 7.2 & 11.2 & 10.9 & 10.9 \\
\hline India & - & 2.2 & 4.3 & 4.4 & 3.5 & & 3.6 \\
\hline Italy & 9.8 & 11.7 & 10.8 & 7.7 & 8.4 & 8.4 & 10.7 \\
\hline
\end{tabular}




\begin{tabular}{|l|r|r|r|r|r|r|r|}
\hline \multicolumn{1}{|c|}{ Country Name } & \multicolumn{1}{c|}{$\mathbf{1 9 9 0}$} & \multicolumn{1}{c|}{$\mathbf{1 9 9 5}$} & $\mathbf{2 0 0 0}$ & $\mathbf{2 0 0 5}$ & $\mathbf{2 0 1 0}$ & $\mathbf{2 0 1 1}$ & $\mathbf{2 0 1 2}$ \\
\hline Morocco & 15.8 & $\mathbf{2 2 . 9}$ & 13.6 & 11 & 9.1 & 8.9 & 9 \\
\hline Moldova & - & - & 8.5 & 7.3 & 7.4 & 6.7 & 5.6 \\
\hline Romania & - & 8 & 7 & 7.2 & 7.3 & 7.4 & 7 \\
\hline Slovak Republic & - & 13.1 & 18.8 & 16.2 & 14.4 & 13.5 & 13.9 \\
\hline Slovenia & - & 7.2 & 6.9 & 6.5 & 7.2 & 8.2 & 8.8 \\
\hline Sweden & 1.8 & 9.1 & 5.8 & 7.7 & 8.6 & 7.8 & 8 \\
\hline Tunisia & - & - & 15.7 & 14.2 & 13 & 18.3 & - \\
\hline Turkey & 8 & 7.6 & 6.5 & 10.6 & 11.9 & 9.8 & 9.2 \\
\hline United States & 5.6 & 5.6 & 4 & 5.1 & 9.6 & 8.9 & 8.1 \\
\hline
\end{tabular}

Note: Unemployment, total (\% of total labor force)

Source: World Development Indicators, data processed by the authors.

Again, we find that the poorest countries, Algeria, Morocco, Colombia, have a very high unemployment rate in 1990, namely $19.8 \%, 15.8 \%$ and $10.2 \%$ respectively. In countries reporting this indicator, we find fairly reasonable rates, such as Brazil 3.7\%, 5.6\% in the United States, $2.5 \%$ in China, which means an increase in the use of labor. Regarding 2012 with adjustments during these 23 years, we find somewhat the same trends. In Egypt, the unemployment rate rose to $12.7 \%$, in Hungary it was $10.9 \%$, in the Slovak Republic 3.9\%, in the United States an increase to $8.1 \%$. As far as our country is concerned, it has seen growth rates between $8.5 \%$ in 2000 and reaching $7 \%$ in 2012 and with fluctuations between $4 \%$ and $4.6 \%$ in 2017 which is reasonable and is somewhat above average registered in the European Union.

\section{- Forecasting the evolution of the world's population}

In a simplified analysis, the problems of human resources and of existing food and development resources remain. First, two decades ago, China was the world's biggest problem in terms of birth and population. Subsequently, India entered, with a large population and, above all, a high birth rate. In the course of the last hundred years, an issue that is becoming worrying is the evolution of the population of the African continent states. From 1917 to 2017, the population of this continent increased from 100 million inhabitants, as it was known, to 1.2 billion inhabitants. Natality in most states of the world, based on female fertility, is 2.6 children/woman in northern Africa and 7.6 children/woman in Niger. The mineral resources discovered so far are in the process of diminishing, if not exhaustion, and the problem of discovering new reserves will be in order to provide an economic development perspective.

In the present study, the authors have proposed to analyze the evolution of global population growth along with the amount of resources attracted to exploitation, research, or predictability of being on Earth. Many researchers, including Lester Brown, Cristophore Flavin and Hillary French, have dealt with the analysis of the world economic situation, starting from the average birth rate on the globe, which is rising compared to any kind of resources that by exploitation, diminished.

In making this study, we must take into account the concrete situation of states on continents, Europe, Asia, North America, South America, Africa, Australia, and why not Oceania.

From the population point of view, China and India were the countries with the highest birth/fertility, especially China, which until 1990 had a very special female birth rate/fertility. China has calmed its birth rate, diminished its fertility, and although it has the largest population of the world, it has managed to balance its birth in the last few decades. From a brief look it follows that the Asian continent is now somewhere in the balance of population and resources, yet with the largest population in the world, from all continents. Two other continents, Europe and Africa, remain to be interpreted. In Europe and Africa there are states that are at the poles of economic evolution, civilization, culture, level of economic development, technical-scientific and research. Natality in the countries of the European Union is very low. For example, Italy and Spain, both of Latin origin. Thus, Italy has a fertility rate of 1.39 live births per woman, and Spain has a fertility rate of 1.27 live births per woman. On average, European countries have a fertility rate of 1.48 per woman. At the opposite end, there are African continent states.

The Middle East region, which is at the confluence of the three continents, Africa, Europe and Asia, where countries have a positive development level, birth/fertility is controllable. 
In the case of Australia, analyzes lead to the conclusion that there is a balance between resources and population. Considering the 100-year period, from 1917 to 2017, and the population growth estimate by 2050, summing up, the data looks like this: Africa had a population of 100 million inhabitants registered in 1917, of a total population of the world of 2 billion inhabitants.

Table 5. Population of African/European countries

- millions of people -

\begin{tabular}{|l|c|c|c|c|}
\hline State & Population 1950/1960 & Population 2017 & Fertility & Prognosed population 2050 \\
\hline Algeria & 11 & 39 & 3.2 & 73 \\
\hline Burkina Faso & 4.8 & 18 & 5.5 & 32 \\
\hline Ciad & 3 & 14 & 6.16 & 31 \\
\hline Egipt & 20 & 95 & 3.34 & 183 \\
\hline Mali & 5.2 & 17.60 & 6.23 & 34 \\
\hline Mauritania & 0,85 & 4 & 4.6 & 7.1 \\
\hline Maroc & 9 & 34 & 2,6 & 68 \\
\hline Niger & 3.4 & 21.50 & 7,6 & 41 \\
\hline Nigeria & 45.2 & 184 & 5.65 & 372 \\
\hline Senegal & 3 & 15 & 5.10 & 29 \\
\hline Italia & 46.5 & 59.5 & 1.39 & 54 \\
\hline Spania & 28.0 & 47.00 & 1.27 & 41 \\
\hline România & 21 & 19.5 & 1.48 & 17 \\
\hline
\end{tabular}

Source: data processed by authors from bibliographic sources

In 2017, so after 100 years, the population of Africa has reached 1.2 billion inhabitants, out of a total of 7.2 billion inhabitants globally. We find that the Earth's population has grown 3.6 times while Africa's population has grown 12 times. In 2050, due to the maintenance of the fertility/birthrate trend as it is in 2017 on all continents, the population of Africa will reach 2.5 billion inhabitants, out of a total of 10 billion inhabitants globally. This results in an increase of more than twice the population of the African states (25\% of the world's population). The total world population will grow about $35 \%$. In 2017, the population aged under 15 was the majority due to the demographic explosion.

Analyzing the situation of immigrants in the Middle East, we find that Italy, first of all, Spain, Portugal, Greece and, above all, Turkey, are the most affected countries. In figure 1 we graphically represented the evolution of the population in some states in Africa and Europe.

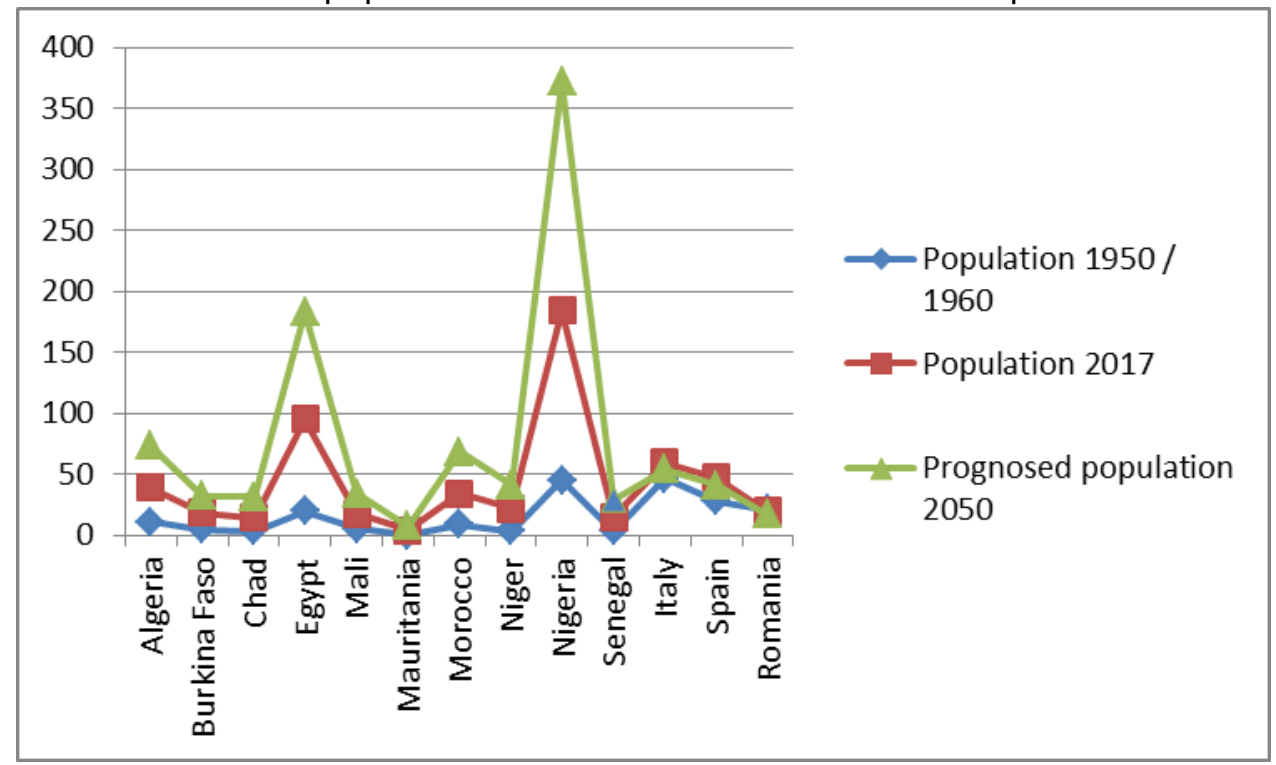

Source: Own representation based on data processed by the authors

Figure 1. The evolution of the population of some African/European countries 
In figure 2 we graphically represented the evolution of fertility in some states in Africa and Europe.

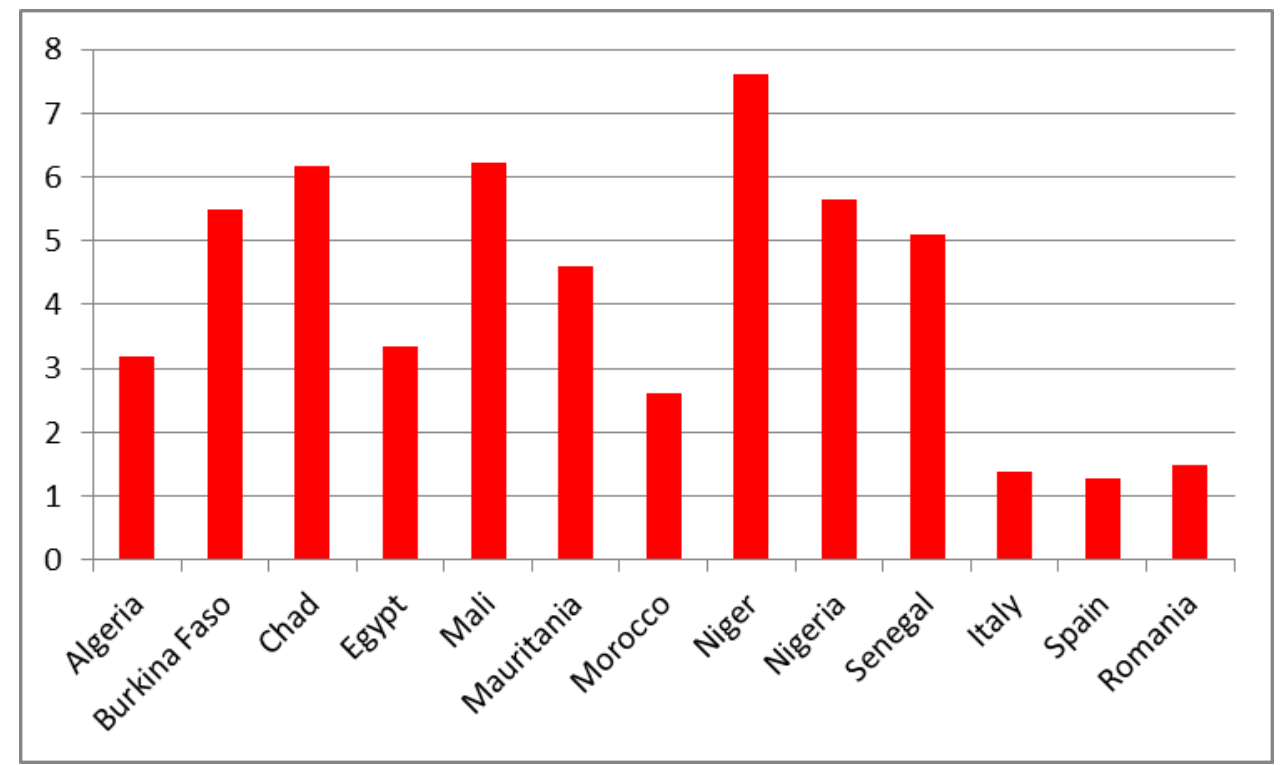

Source: Own representation based on data processed by the authors

Figure 2. Evolution of the fertility of some African/European states

In 2017, fertility was: in Africa, on average 4.7 children born to a woman in Asia 2.2 children born to a woman and in Europe 1.48 children born to a woman.

In 2050, Burkina Fasso will reach 60 million inhabitants, and Nigeria will have around 400 million inhabitants, that is, more than the United States to highlight an equivalence criterion.

In a study published by the Worldwatch Institute (USA), it was mentioned that "if the exodus of the African population through immigration that can stifle Europe can not be stopped, we can talk about Europe as Africa over the lake shortly," increases the population of states in the European continent, ie being "above the lake" across the Mediterranean Sea. The African continent remains the one with the highest demographic explosion and will face severe poverty. Seven years ago, Berlusconi and Ghadaffi predicted that Europe would be assaulted by African emigrants.

The dilemma of immigration has, as we have seen, determined Brexit of Great Britain, and Poland, Hungary, the Czech Republic and Slovenia, together, are trying to oppose this phenomenon. Politicians in the European continent do not regard African emigration as simply invasion. Until now, 10 million Africans have joined Europe, equal to the Hungarian population or half that of Romania. De Gaulle said in his time that "individuals can be integrated, but peoples can never be integrated."

In 2016, 93\% of immigrants settled in Europe were Africans, and in 2017, in 6 months, 100,000 citizens from sub-Saharan states entered Italy. The group of 20 states launched the "Compact with Africa" project, in which 13 million euros will be used to fight corruption and the attempt for a Marshall Plan desired by Africans to develop in this respect.

\section{- Analyze resources of humanity}

We must aim at stopping the decline, moving to prospecting for new resources so that we can get where it should be, ie to increase the level of exploited/exploitable resources that will ensure the possibility of economic development, but also the ability to feed the population of the globe.

We anticipate a surprise of the environment, in the sense that tropical forests will have to be correlated, the seas and oceans have their vegetation to be exploited.

Agriculture, which is well developed and represented in the world. Irrigation involves technology and other expenses that require everyone to use the first natural resources we have, namely arable/agricultural land. The question is, "How can we extend irrigation to the situation of poor farmers?" 
We can not overlook the emergence of overeating in the areas of huzur and luxury, compared to a fairly modest diet and social assistance.

The social costs of eating are incorrectly distributed across the globe and the effects are easy to see and anticipate. The removal of existing organic pollutants is another element to be considered in the context of natural reserves being affected by unprecedented environmental pollution. The forest system led, through the irrational deforestation system in many parts of the world, to changing the environment.

Information technology should be used for the environment. Global expansion is a term, but reality is a delicate one. Miniaturized development - micro-plants, micro-hydropower plants and other wind-can bring an increase in energy to be used for the purposes and benefits of humanity.

In the 21st century, we pose the problem that the population that is in expansionary growth also benefits from a job on an environmental protection fund. Energy restructuring, material recovery and other economic actions of this kind must be taken into account.

Innovations that appear to be transposed into global environmental governance. Economic and financial crises are no longer limited to one territory or another, but affect the entire population of the globe in varying degrees.

A correlative analysis of population growth on the globe with the prospect of diminishing and replacing natural resources, the natural, logical and scientific question is "where does mankind go?"

International, economic and technical-scientific cooperation requires funds to be directed to areas with resources, but without opportunities, but in fairness and realism in these investments.

A generic Marshall Plan is not feasible for Africa.

The future of mankind is not gloomy, but it is sensitively affected by the discrepancy between the natural growth of the population and the improvement of the exploitation, capitalization of the natural resources.

\section{Conclusions}

From the study we draw some conclusions on very important issues.

Thus, the population of the globe in the present and prospective conditions until 2050 will continue to rise in an unbalanced way, with a very high birth rate in African countries, a reasonable birth rate in Asia and especially in the Americas, and a worrying decrease in female birth/fertility in European countries.

This population development will create problems in certain areas of the globe, primarily in Africa and other Asian countries or even Latin America, which will have to be globally attracted to an area of interest for all the Territories.

It also comes to the conclusion that resources in exploitation, exploitable or under prospecting to be exploited in the future are becoming less and the costs for research, prospecting and then exploitation will be quite high so countries that, even if they have resources on their own territory, will not be able to capitalize on their national wealth in their own interests what will affect and affect the global interest.

Globalization is a process, it is a phenomenon, but, first of all, it is a certain perspective of the evolution of mankind in the future.We can also conclude that greater population density is needed in countries and continents closer to the realities of resources in those areas or elsewhere. Cooperation in production, research, and, above all, support for these processes are defining elements of the coming periods. The final conclusion is that careful depth studies are required to ascertain the current state of evolution of mankind, and on the basis of forecasts, to identify the parallel trend that population growth will have with that of production and general resources that it will have mankind.

\section{References}

1. Anghelache, C., Barbu, C.M and Anghel, M.G. (2018). Analysis of population and world resources evolution and perspectives. Romanian Statistical Review Supplement, 4, 107-123.

2. Anghelache, C. (2017). România 2017. Starea economică la un deceniu de la aderare, Editura Economică.

3. Anghelache, C. and Anghel, M.G. (2017). România - membră a Uniunii Europene. Zece ani de la aderare, Editura Economică, Bucureşti. 
4. Anghelache, C. and Anghel, M.G. (2017). The European Union's strategy for increasing the living conditions of the population in the member states. Theoretical and Applied Economics, XXIV (3), (612), Autumn, 5-18.

5. Anghelache, C. and Anghel, M.G. (2016). Bazele statisticii economice. Concepte teoretice şi studii de caz, Editura Economică, Bucureşti.

6. Anghelache, C. (2008). Tratat de statistică teoretică şi economică, Editura Economică, Bucureşti.

7. Benjaminsen, T.A., Holden, S.T., Lund, C. and Sjaastad, E. (2009). Formalisation of land rights: some empirical evidence from Mali, Niger and South Africa. Land Use Policy, 26, 28-35.

8. Canadell, J.G. and Raupach, M.R. (2008). Managing forests for climate change mitigation. Science, $320,1456-1457$.

9. DeFries, R., Rudel, Th., Uriarte, M. and Hansen, M. (2010). Deforestation driven by urban population growth and agricultural trade in the twenty-first century. Nature Geoscience, 3, 178-181.

10.Das, M. and Mohanty, S. (2012). Spatial pattern of fertility transition in Uttar Pradesh and Bihar: a district level analysis. Genus Journal, 68 (2), 81-106.

11.Dudgeon, D., Arthington, A., Gessner, M. et al. (2006). Freshwater biodiversity: importance, threats, status and conservation challenges. Biological Reviews, 81 (2), 163-182.

12.Fargione, J., Jason, H., Tilman, D., Polasky, S. and Hawthorne, P. (2008). Land clearing and the biofuel carbon debt. Science, 319, 1235-1238.

13. Headey, D. and Hodge, A. (2009). The Effect of Population Growth on Economic Growth: A Meta-Regression Analysis of the Macroeconomic Literature. Population and Development Review, 35 (2), 221-248.

14. Holden, S. and Otsuka, K. (2014). The roles of land tenure reforms and land markets in the context of population growth and land use intensification in Africa. Food Policy, 48, 88-97.

15.Jorgenson, A. and Burns, T. (2007). Effects of rural and urban population dynamics and national development on deforestation in less-developed countries, 1990-2000. Sociological Inquiry, 77 (3), $460-$ 482.

16.Mendez, M.A. and Popkin, B.M. (2004). Globalization, urbanization and nutrition change in the developing world. Journal of Development and Agricultural Economics, 1 (2), 220-241.

17.Mishra, T. (2008). Stochastic Demographic Dynamics and Economic Growth: An Application and Insights from the World Data. Historical Social Research, 33 (4) (126), 9-187.

18. Montgomery, M.R. (2008). The urban transformation of the developing world. Science, 319, 761764.

19. Wittemyer, G., Elsen, P., Bean, W., Burton, C. and Brashares, J. (2008). Accelerated Human Population Growth at Protected Area Edges. Science, 321 (5885), 123-126. 